\title{
The Institutional Study of Government Think Tank'
}

\author{
Muhyiddin², Guspika, Sumedi Andono Mulyo, M Firman Hidayat, Istasius Angger \\ Anindito, and Yogi Harsudiono \\ Ministry of National Development Planning/BAPPENAS
}

\begin{abstract}
The government think tank institution basically serves as a bridge between science and government policy. One of Bappenas duties and functions is as a government think tank. To find the appropriate institutional form, this study elaborates the institutional think tanks of foreign governments. This qualitative approach describes some of the best practice models including the Korean Development Institute (KDI) - South Korea, the National Institution for Transforming India (NITI) Aayog - India, the National Economic and Social Development Board (NESDB) - Thailand, and Productivity Commission (PC) - Australia. From these 4 institutional models, this study provides 4 alternative options as recommendations. First, the government can revitalize some organs in Bappenas to become a government think tank unit. If the Bappenas institution still holds the planning and budgeting functions, this is the best fit. It refers to NSEBD - Thailand. Second, transform Bappenas into a whole government think tank, with reference to NITI Aayog - India. Third, releasing work units implementing think tank functions at Bappenas to become a special think tank under Bappenas, with reference to KDI - South Korea. Fourth, new institutional think-tanks are formed under the president by utilizing the existing government think tank institutional resources such as Bappenas and Research and Developoment Units under line ministries.
\end{abstract}

Keywords: government think tank, knowledge policy

1 This manuscript is adapted from the study conducted by Tim Analisis Kebijakan (TAK) Bappenas in 2015 titled "Studi Model Hubungan Kerja Kelembagaan Think Tank Pemerintah dengan Penentu Kebijakan" and "Think Tank Bappenas", where the authors were the researchers on those studies.

2 Muhyiddin is a Senior Planner at Ministry of National Development Planning/BAPPENAS. Email address: udyn@bappenas. go.id. Guspika, Sumedi Andono Mulyo, M Firman Hidayat, Istasius Angger Anindito, and Yogi Harsudiono are Planners at Ministry of National Development Planning/BAPPENAS. 


\section{Studi Kelembagaan Think Tank Pemerintah}

Muhyiddin, Guspika, Sumedi Andono Mulyo, M Firman Hidayat, Istasius Angger Anindito, dan Yogi Harsudiono, BAPPENAS

\section{Pendahuluan}

\subsection{Latar Belakang}

Lembaga think tank pemerintah pada dasarnya berfungsi sebagai jembatan antara ilmu pengetahuan dan kebijakan pemerintah. Kompleksitas permasalahan pembangunan yang dari waktu ke waktu semakin berat menjadi tantangan pemerintah untuk dikelola dan diatasi berdasarkan ilmu pengetahuan. Lembaga think tank pemerintah merumuskan bagaimana ilmu pengetahuan tersebut ditransformasikan melalui riset kebijakan sehingga dihasilkan solusi kebijakan yang teruji.

Korea Selatan (Korsel) sekarang menjadi salah satu raksasa ekonomi dunia, dengan luas negara yang jauh labih kecil dibanding Amerika Serikat atau Indonesia dan tidak mempunyai sumber daya alam melimpah. Apa yang membuat negara bekas jajahan Jepang ini melejit sebagai salah satu kekuatan baru dalam perekonomian dunia? Dengan tidak menegasikan faktor-faktor lain yang penting, salah satu faktornya adalah adanya strategi pembangunan jangka panjang, menengah dan pendek yang disusun, disinergikan, dan diskenariokan dengan sangat baik oleh lembaga think tank yang dimiliki pemerintahnya. Lembaga tersebut adalah Korean Development Institute (KDI). KDI merumuskan sebuah rencana strategis yang komplemen dan paralel mulai investasi, penelitian dan pengembangan teknologi tinggi, penyediaan infrastruktur, pembangunan basis industri manufaktur yang kuat, serta penyiapan sumber daya manusia yang berkualitas. KDI menjadi 'jembatan' yang mengantarkan stok ilmu pengetahuan yang ada di Korsel untuk disinergikan dan diimplementasikan melalui kebijakan pemerintahan Korsel. Gabungan seluruh kekuatan yang ada itulah yang membuat Korsel seperti sekarang ini, yaitu menjelma dari negara yang tadinya terbelakang dengan pendapatan per kapita hanya 103 dollar AS di tahun 1964 menjadi raksasa ekonomi dunia dengan pendapatan per kapita 23.000 dollar AS di tahun 2013.

Sebelumnya, pada tahun 1960an Korsel adalah termasuk negara miskin dan tidak punya sumber daya alam melimpah. Pada tahap awal pembangunan pemerintah Korsel sangat mengandalkan utang luar negeri dan investasi asing. Tetapi sangat tidak mudah untuk memperolehnya. Pemerintah Korsel harus mengirimkan kompensasi dari bantuan mengikat dari donor-donor Amerika dan Eropa berupa pengiriman pasukan ke Vietnam, tenaga kasar untuk proyek-proyek pembangunan di Timur Tengah, atau mengirim perawat ke Jerman dan Eropa. Dari sumber-sumber pendanaan yang cukup ketat itulah KDI merumuskan rencana pembangunan yang terintegrasi dari semua potensi yang ada dan pemerintah Korsel melaksanakan secara konsisten, lalu jadilah Korea semacam ini.

Joong Kyung Choi (2013) menyebutkan 4 (empat) pilar yang menjadi pondasi kokoh pembangunan di Korsel, yaitu kepemimpinan dengan visi yang benar, rencana yang diorganisasikan dengan baik, lalu aparat pemerintahan yang siap melaksanakan rencana dengan konsisten, dan terakhir harus ada biaya untuk mengeksekusinya.

KDI berdiri di tahun 1971, masa dimana pemerintahan Korea dipimpin oleh diktator militer Park Chung Hee (ayahanda dari presiden Korea sekarang, Park Gyun Hye). Waktu itu Pemerintah Korea mengumpulkan putra-putri terbaiknya 
yang dididik di Amerika Serikat, Jepang, dan Eropa untuk menyusun sebuah rencana induk pembangunan jangka panjang Korea. Sebagai lembaga yang awalnya berada di bawah Economic Planning Board (Bappenas-nya Korsel), KDI kemudian bertransformasi menjadi think tank lembaga kepresidenanan melalui Badan Konsultasi Restrukrisasi Perekonomian. Jika awalnya KDI lebih banyak mengandalkan metode validasi pakar (expert judgement) dari para cerdik pandai (scholar) asli Korsel yang dikumpulkan dari lembaga pendidikan terbaik di dunia, maka kini KDI berkembang dengan semua perangkat think tank mulai dari penelitian, kertas kerja, lembar diskusi, laporan perkembangan, studi evaluasi, dan penerbitan buku serta jurnal kebijakan. KDI memberikan kontribusi substantif kepada pemerintah dan masyarakat serta sektor publik dan swasta dengan memberikan alternatif kebijakan yang tepat dan efektif. KDI mengusulkan rekomendasi kebijakan yang akan menjadi fondasi inti Korsel untuk pertumbuhan ekonomi dunia. Selain itu, KDI membangun kapasitas organisasi sebagai lembaga kebijakan yang berfungsi sebagai kompas bagi para pembuat kebijakan ekonomi di pemerintahan Korsel.

Lalu bagaimana dengan Indonesia sendiri, apakah sudah punya lembaga yang berfungsi sebagai think tank pemerintah? Dalam struktur pemerintah pusat fungsi think tank ada pada Badan Perencanaan Pembangunan Nasional (Bappenas). Bappenas sebagai think tank cakupan tugasnya adalah meliputi fungsi pengkajian kebijakan di bidang perencanaan pembangunan, fasilitasi instansi pusat dan daerah, serta kerjasama dengan perguruan tinggi. Namun jika menilik pada alat kelengkapan lembaga think tank, maka Bappenas dapat dikatakan sangat tertinggal.

Perpres nomor 20/2016 tentang struktur organisasi, tugas, dan fungsi Kementerian Perencanaan Pembangunan Nasional dan Badan Perencanaan Pembangunan Nasional memberikan salah satu tugas dan fungsi secara resmi sebagai lembaga think tank pemerintah.

Kajian ini mencoba mengelaborasi sebuah studi kualitatif dengan pendekatan komparatif kepada lembaga-lembaga think tank pemerintah yang dapat menjadi best practices untuk Bappenas. Bagaimana Bappenas menerapkan tusi sebagai lembaga think tank pemerintah tapi dapat mengadopsi sebuah model lembaga yang menjadi jembatan antara penelitian menuju kebijakan, jembatan antara pengetahuan menuju kekuasaan (bridging knowledge to policy).

\subsection{Tujuan dan Metodologi}

Dalam konteks kebijakan publik dan perencanaan pembangunan, peran lembaga think tank pemerintah sangat penting untuk mendukung lahirnya kebijakan-kebijakan publik yang berkualitas dan rencana pembangunan yang realistis, terukur dan implementabel.

Tujuan kajian ini adalah merumuskan model kelembagaan Bappenas atau di Bappenas yang tepat untuk menjadi sebuah lembaga think tank pemerintah Indonesia, dan diharapkan menjadi jembatan yang berfungsi sebagai 'bridging knowledge to policy' yang melahirkan kebijakan pembangunan yang realistis, terukur dan implementabel.

Metodologi yang dilakukan dalam kajian ini menggunakan pendekatan studi kualitatif dengan menguraikan praktik-praktik terbaik (best practices) obyek sejenis di mancanegara melalui studi pustaka/literature (desk study), kelompok diskusi terfokus (focus group discussion), dan wawancara narasumber terpilih berdasarkan kompetensi. 


\section{Studi Best Practices Lembaga Think Tank Pemerintah Mancanegara}

\subsection{Korea Development Institute}

Korea Development Institute (KDI) didirikan pada tahun 1971 di masa Pemerintahan Park Chung-hee. Ketika itu, Republik Korea merupakan salah satu negara paling miskin di dunia, dengan pendapatan per kapita sebesar USD 71 (peringkat 121 dari 125 negara) pada 1961.

\section{Awal Pemerintahan Park Chung-hee}

Presiden Park Chung-hee memerintah selama hampir 4 periode yaitu sejak 1961-1979. Presiden Park merebut kekuasaan melalui kudeta militer yang menggulingkan Republik Korea Kedua pada tahun 1961 dan memerintah walaupun bukan sebagai pilihan utama para perwira militer ketika itu sampai pemilu dan pelantikan sebagai Presiden dari Korea Republik Ketiga pada tahun 1963. Pada tahun 1972, Presiden Park mengumumkan darurat militer, membekukan konstitusi negara lalu membuat dirinya Presiden Seumur Hidup sementara mengantarkan Korea Republik Keempat karena ancaman komunis konstan dalam bangsa. Meskipun hidup beberapa upaya pembunuhan, termasuk dua operasi oleh agen Korea Utara, Presiden Park akhirnya dibunuh pada tanggal 26 Oktober 1979 oleh kepala jasa keamanannya sendiri. Dia memimpin Republik Korea selama 18 tahun. Presiden yang terkenal autoritarian inilah yang membawa Republik Korea meletakkan dasar-dasar pembangunan ekonominya.

Presiden Park banyak disebut memainkan peran penting dalam pengembangan Republik Korea yang pada periode itu disebut sebagai 'harimau ekonomi' dengan menggeser fokusnya dari negara agraria menjadi negara industrialisasi berorientasi ekspor. Ketika Presiden Park berkuasa pada tahun 1961, pendapatan per kapita Korea Selatan hanya USD 72 (peringkat 121 dari 125 negara). Presiden Park menciptakan lembaga pembangunan ekonomi, yakni: (1) Badan Perencanaan Ekonomi (EPB), (2) Departemen Perdagangan dan Industri (MTI), dan (3) Departemen Keuangan (MoF) yang bertanggung jawab untuk menyipkan rancangan pembangunan ekonominya. Karena pentingnya EPB, kepala EPB ketika itu menjabat sekaligus sebagai deputi I Perdana Menteri. Kebijakan-kebijakan yang dituangkan oleh EPB dalam rencana lima tahunan ini bagi sebagian besar pihak banyak disebut menjadi tonggak bangkitnya ekonomi Korea. EPB yang mendorong kebijakan promosi ekspor berhasil mengangkat industri Korea menjadi maju dan meningkatkan kontribusi ekspor terhadap PDB menjadi 35 persen (1980-an), dibandingkan 5 persen (1950-an).

Secara singkat, performa Presiden Park dan dua kali lima-tahunan perencanaan EPB sebagai berikut: Republik Korea berhasil tumbuh lebih baik daripada masa pemerintahan sebelumnya, Presiden Rhee. Presiden Rhee gagal meningkatkan perekonomian Korea Selatan paska terjadinya Perang Korea. Presiden Park pada pemerintahannya fokus untuk mengembangkan Kebijakan Industri Berbasis Ekspor. Kebijakan tersebut berhasil ditandai dengan meningkatnya kontribusi ekspor produk industri (terutama tekstil, sepatu dan apparel) terhadap PDB dan baiknya indikator keunggulan komparatif (comparative advantages). Kebijakan ini membuat Presiden Park sebenarnya memiliki kredit yang besar di mata masyarakat Korea Selatan dan Presiden Park memenangkan pemilu berikutnya pada tahun 1971.

\section{Tentang KDI}

KDI telah jauh diakui sebagai institusi terkemuka think tank pemerintah dari Republik Korea dan berkontribusi pada kondisi sosial ekonomi dan pembangunan Republik Korea. Selama lebih dari tiga dekade, KDI secara konsisten menyediakan rekomendasi kebijakan (policy recommendation) dan petunjuk (guidance) 
berdasarkan analisis mengenai mendalam internasional maupun dalam negeri kondisi ekonomi dan melakukan proyeksi preventif dalam melakukan dan studi empiris. Studi empiris dalam membuat policy recommendation sangat diperlukan agar justifikasi dalam sebuah kebijakan publik dapat dipertanggung jawabkan secara akademik tidak berdasar keputusan politis semata.

Sementara menyadari pentingnya menemukan sumber pertumbuhan ekonomi baru untuk upaya pemulihan ekonomi yang keberlanjutan sewaktu terjadi krisis ekonomi global, KDI bekerja keras untuk menyusun Arah Kebijakan (policy directions) berdasarkan kebijakan yang komprehensif. Rancangan kebijakan tersebut telah melalui tahapan yang dapat dipertanggungjawabkan secara akademis dan melalui proses semacam tinjauan ulang sesama ilmuan dan ahli (peer-reviewed).

Dengan terus meningkatkan kapasitas penelitian dan kerjasama internasional, KDI akan menjadi bertaraf internasional yang: unggul dalam melakukan penelitian, dapat merumuskan kebijakan ekonomi preventif dan bisa dijalankan, dan pada saat yang sama memperkuat kapasitas komprehensif dalam melakukan studi akademis. Sejalan dengan penelitian yang dilakukan, KDI akan berusaha untuk terus-menerus melakukan diseminasi informasi mengenai isu-isu kebijakan ekonomi untuk pemangku kepentingan bidang ekonomi.

\section{Produk KDI}

Korean Development Institute bertanggung jawab untuk menyusun, antara lain:

a. Membuat draft masukan untuk Dokumen Perencanaan Tiga Tahunan (berjudul Three Years Innovation Plan) d/h. Dokumen Perencanaan Lima Tahunan yang dikeluarkan oleh MoSF.

b. Membuat penilaian terhadap dokumen pre-feasibility study (Pre-FS) yang dibuat oleh Kementerian sektoral.

c. Melakukan kajian sosial dalam bentuk Research Based Policy, contoh Economic Outlook.

d. Mengeluarkan buletin bulanan, contoh: KDI Economic Buletin, Monthly Economic Trends

e. Menyelenggarakan konference internasional, contoh: KDI Journal of Economic Policy Conference.

Bahan-bahan tersebut disusun dan diserahkan kepada MoSF sebagai bahan masukan ketika MoSF mendesain program dan kegiatan. Tanggung-jawab pengambilan keputusan bukan merupakan kewenangan KDI, namun merupakan kewenangan MoSF. Dalam prakteknya, karena kredibilitas yang tinggi hasil assesment dan rekomendasi KDI hampir selalu ditindaklanjuti.

\section{Struktur Organisasi dan Hubungan Tanggung Jawab}

Di KDI terdapat total 360 peneliti dan 60 staf administrasi. Seluruhnya merupakan pegawai tetap di KDI yang statusnya adalah non-PNS. KDI juga bukan merupakan organ pemerintah. Sehingga hubungan antara KDI dan MoSF juga tidak sepenuhnya tergambarkan dalam dokumen resmi pemerintah Republik Korea.

Tanggung jawab pekerjaan dan pelaporan hasil pekerjaan dilakukan oleh KDI kepada MoSF langsung. Walaupun KDI bukan merupakan organ pemerintah, KDI menerima anggaran untuk melaksanakan pekerjaannya juga melalui MoSF.

Di dalam KDI, staf peneliti ditempatkan kedalam unit kerja yang disebut Departement sesuai dengan bidang keahliannya. Saat ini terdapat tujuh departemen seperti yang ditunjukkan dalam gambar. Penentuan tujuh unit kerja tersebut disesuaikan dengan perkembangan zaman dan isu yang relevan dengan Republik Korea. Saat ini sudah tidak dijumpai unit kerja kemiskinan atau infrastruktur, karena Republik Korea sudah melalui tahapan tersebut. Saat ini Dept 
Gambar 1. Struktur Organisasi Korean Development Institute

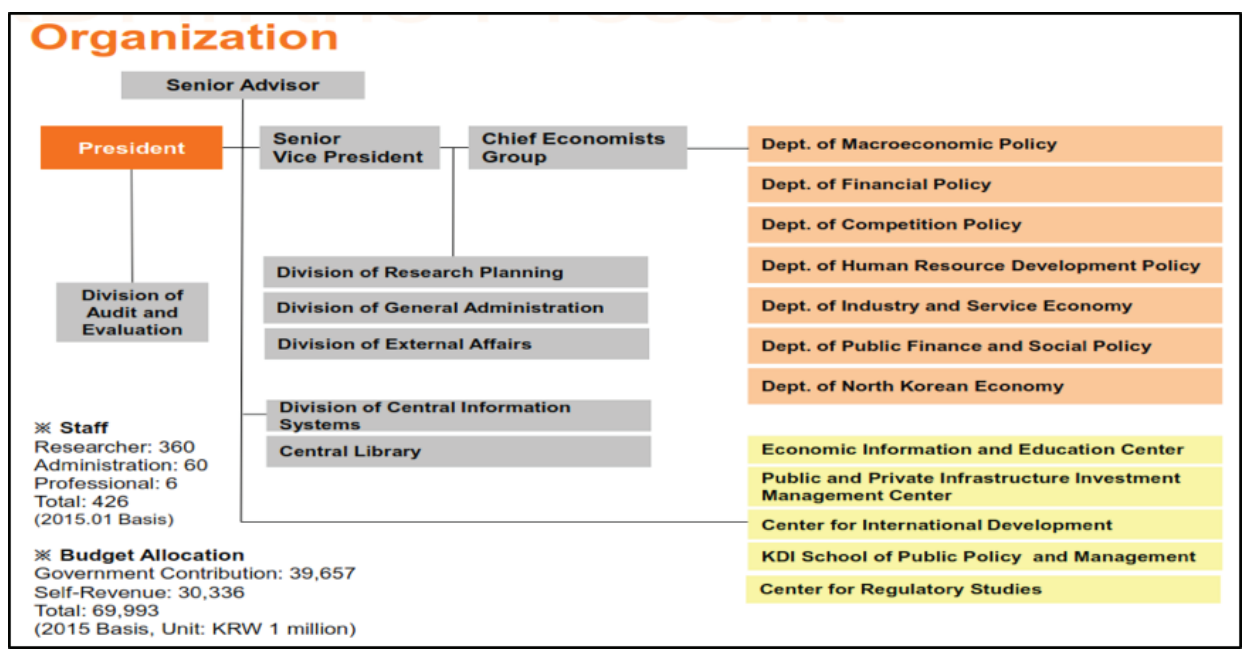

Sumber: Laman KDI http://www.kdi.re.kr/kdi_eng/

Selain unit kerja yang sifatnya struktural, KDI juga memiliki beberapa pusat untuk mendukung dan membantu para peneliti serta pihak eksternal untuk diseminasi dan peningkatan kapasitas, seperti Center for Education and Economic Information dan Public-Private Infrastructur Investment Management Center (PIMAC).

Beberapa catatan tentang perkembangan Korea dan peran KDI sebagai lembaga think tank pemerintah diuraikan sebagai berikut:

1. Republik Korea mampu tumbuh dari negera miskin di awal 1960-an (GDP percapita \$71) menjadi salah satu negara paling maju di dunia dikarenakan transisi yang baik dari negara agrikultur menjadi negara industri. Kredit kepada pemerintah banyak disematkan bagi Presiden Park Chung-hee karena pada 18 tahun masa pemerintahannya kebijakan pemerintah mampu mendorong pertumbuhan ekonomi Korea Selatan dengan sangat tinggi dan dapat berkelanjutan. Peran nyata pemerintah dalam membuat perencanaan yang baik dalam hal ini sangat krusial.

2. Bantuk kelembagaan yang melakukan fungsi perencanaan dan anggaran seringkali berubah, sejak 1949 hingga 2015 terjadi beberapa kali perubahan bentuk, yakni secara singkat: EPB+MoF -> MoFE -> MoFE+NBC+FSC+MoFAT -> MoFE+MoPB -> MoSF. Terlepas dari perubahan dan siapapun lembaga yang berwenang untuk membuat perencanaan jangka panjang dan menengah hingga tahunan harus mampu mengambil kebijakan yang baik. Fungsi KDI adalah sebagai lembaga non-pemerintahan yang menjadi dewan pertimbangan profesional (advisory-body) untuk melakukan kajian sebagai landasan terciptanya budaya research based-policy. Research based-policy ini dilakukan untuk menjamin kualitas belanja pemerintah yang lebih baik, dan mengurangi risiko kegagalan proyek dan program.

3. Bentuk organisasi KDI yang disesuaikan dengan kondisi/isu kekinian dan rendahnya birokrasi yang terlibat dalam proses 'think tank' merupakan salah satu kunci diperolehnya kredibilitas yang dimiliki oleh KDI hingga saat ini. MoSF bertanggungjawab moral untuk menindaklanjuti rekomendasi 
KDI. Dalam kasus MoSF mengambil keputusan yang berlawanan dengan $\mathrm{KDI}$, badan pemeriksa keuangan dan pembangunan dapat menanyakan argumentasi ilmiah dibalik diambilnya kebijakan tersebut.

\subsection{National Institution for Transforming India (NITI) Aayog}

Sejak awal Januari 2015, pemerintah India membentuk lembaga baru, lembaga think tank pemerintahan, dengan nama National Institution for Transforming India (NITI) Aayog. Lembaga baru ini menggantikan peran lembaga perencanaan pemerintah, Planning Commission, yang secara resmi dibubarkan di waktu yang sama. Dibubarkannya Planning Commission dan berdirinya NITI menandai era baru dalam pengambilan kebijkaan pemerintah India, dari sistem perencanaan yang sepenuhnya diatur oleh negara menjadi perencanaan yang bersifat strategis dengan pendekatan ekonomi pasar.

Peran lembaga perencanaan yang kemudian digantikan oleh lembaga think tank pemerintahan juga terjadi di banyak negara. Namun kasus India adalah kasus terbaru. Proses transisi yang terjadi di India bisa menjadi pelajaran bagi Indonesia, lebih khusus Bappenas, dalam usaha untuk membentuk lembaga think tank pemerintahan. Terkait dengan itu, subbab ini akan membahas lebih dalam proses perubahan dari Planning Commission menjadi NITI Aayog: (1) faktor-faktor yang melatarbelakangi; (2) peran dan fungsi NITI Aayog dan perbedaaan dengan Planning Commission; dan (3) permasalahan yang terjadi pada proses transisi.

\section{Perubahan dari Planning Commission ke NITI Aayog}

Planning Commission punya sejarah yang panjang dan peran yang cukup besar dalam proses pembangunan di India. Planning Commission, yang dibentuk pada tahun 1951 dan dipimpin pertama kali oleh Perdana Menteri Jawaharlal Nehru, merupakan tindak lanjut dari Resolusi Pemerintah India pada Maret 1950 yang menargetkan peningkatan standar hidup masyarakat melalui eksploitasi sumber daya yang efisien, peningkatan produksi dan kesempatan kerja bagi seluruh lapisan masyarakat. Melalui rencana pembangunan lima tahunan, Planning Commission bertanggung jawab menyusun rencana penggunaan sumber daya yang paling efektif dan seimbang dan menentukan prioritas pembangunan nasional. Sejak tahun 1951 hingga 2015, Planning Commission sudah menyusun dua belas (12) rencana pembangunan lima tahunan.

Dalam perjalanannya, peran Planning Commission mendapatkan berbagai sorotan, terutama seiring dengan perubahan sosioekonomi di masyarakat. Pendekatan perencanaan yang digunakan dalam Planning Commission adalah pendekatan yang dianggap sudah usang dan digunakan untuk era yang berbeda. Planning Commission dituntut untuk berevolusi, mencari peran baru yang lebih relevan dengan kondisi sosioekonomi masyarakat terkini dan supaya bisa lebih efektif dalam melakukan proses perencanaan di tengah berbagai reformasi ekonomi yang ada.

Namun hingga akhirnya dibubarkan, evolusi yang diharapkan tidak terjadi dan menjadi alasan utama di balik dibubarkannya Planning Commission dan digantikan oleh NITI Aayog. Dalam dokumen pembentukannya disebutkan bahwa NITI Aayog dilatarbelakangi perlunya paradigma baru dalam pemerintahan dimana peran pemerintah harus berevolusi dari sekadar mengalokasikan sumberdaya dalam sistem yang terpusat menjadi memberikan arahan strategis, mendukung, dan mengatur sistem yang lebih ke berbasis pasar. Dalam dokumen yang sama juga disebutkan bahwa pemerintah harus melakukan transisi dari pemain utama dalam ekonomi menjadi pendorong dan pembimbing yang dapat mendorong terciptanya semangat entrepreneurship dan berkembangnya sektor swasta, dari skala mikro hingga besar. 
Perdana Menteri Narendra Modi dalam berbagai kesempatan menyampaikan bahwa ada tiga prinsip utama agenda pembangunan yang diusung oleh NITI Aayog, yakni pro-rakyat, proaktif, dan partisipatif. NITI Aayog diharapkan juga menjadi inkubator ide bagi pelaksanaan pemerintahan yang efektif. Secara resmi, tujuan dari NITI Aayog adalah mengembangkan visi ke depan prioritas, sektor, dan strategi pembangunan national dengan keterlibatan aktif dari pemerintah daerah. Untuk mencapai tujuan tersebut secara umum NITI Aayog akan melakukan:

- Memberikan input dan arah strategis pada proses pengambilan kebijakan

- Mengembangkan mekanisme penyusunan rencana yang kredibel dimulai dari tingkat desa untuk kemudian diagregasi secara progresif ke tingkat pemerintahan yang lebih tinggi

- Memastikan kepentingan keamanan nasional sudah masuk dalam strategi dan kebijakan ekonomi

- Memberikan perhatian khusus pada kelompok masyarakat yang beresiko tidak menerima manfaat yang cukup dari kemajuan ekonomi

- Berkomitmen pada federalism kooperatif melalui: (1) keterlibatan masyarakat secara aktif; (2) akses kesempatan yang sama bagi semua; (3) pemerintahan yang adaptif dan partisipatif; (4) penggunaan teknologi.

- Digambarkan pada gambar, untuk mencapai tujuannya, ada tiga fungsi utama yang diemban oleh NITI Aayog: (1) mendorong pluralisme dan desentralisasi; (2) think tank pemerintahan; dan (3) fasilitasi implementasi.

- Dalam perkembangannya NITI Aayog juga dibebani tugas-tugas lainnya. NITI Aayog saat ini diharapkan untuk mengevaluasi efektivitas proyekproyek yang didanai oleh World Bank. Selain itu, proyek-proyek besar harus mendapatkan persetujuan terlebih dahulu dari NITI Aayog. Salah satu contoh terbaru adalah pembangunan kereta cepat yang melalui persetujuan dari NITI Aayog.

Tabel 1. Perbedaan Planning Commission dan NITI Aayog

\begin{tabular}{|c|c|c|}
\hline & Planning Commission & NITI Aayog \\
\hline $\begin{array}{l}\text { Rencana } \\
\text { Pembangunan }\end{array}$ & $\begin{array}{l}\text { Merancang rencana lima } \\
\text { tahun nasional }\end{array}$ & $\begin{array}{l}\text { Mendesain agenda } \\
\text { (strategic) }\end{array}$ \\
\hline Sifat Rencana & \begin{tabular}{|lrr|}
\multicolumn{2}{|l}{ Menetapkan } & kebijakan \\
nasional & dan & daerah \\
lengkap & dengan & alokasi \\
dananya & &
\end{tabular} & $\begin{array}{l}\text { NITI adalah lembaga think tank } \\
\text { (policy formulation hub), } \\
\text { kewenangan alokasi diberikan } \\
\text { kepada kementerian keuangan }\end{array}$ \\
\hline Ukuran Lembaga & $\begin{array}{l}\text { Relatif besar dangan } \\
\text { banyak anggota tetap }\end{array}$ & $\begin{array}{l}\text { Lebih kecil dengan banyak } \\
\text { anggota tentative }\end{array}$ \\
\hline Peran Daerah & \begin{tabular}{|l|} 
Daerah tergabung dalam \\
National Development \\
Council
\end{tabular} & $\begin{array}{l}\text { Daerah tergabung } \\
\text { toverning Council }\end{array}$ \\
\hline Pendekatan & Top Down & $\begin{array}{l}\text { Bottom Up (memfokuskan } \\
\text { pengamatan pada permasalahan } \\
\text { di tingkat lokal) }\end{array}$ \\
\hline
\end{tabular}

Tabel di atas menggambarkan perbedaan fungsi antara Planning Commission dengan NITI Aayog. Salah satu perbedaan yang paling nyata adalah jika Planning Commission memiliki budget power, NITI Aayog tidak. Dengan dibubarkannya Planning Commission, semua wewenang alokasi anggaran ada di bawah Kementerian Keuangan. 


\section{Struktur Organisasi NITI Aayog}

Saat ini NITI Aayog dipimpin langsung oleh perdana menteri, dengan wakil ketua setingkat menteri. Anggota komite diisi oleh Menteri Keuangan, Menteri Dalam Negeri, Menteri Kereta Api, dan Menteri Pertanian. Anggota part time maksimum bisa diisi oleh dua orang dari institusi yang relevan. Governing Council berisikan kepala pemerintah daerah yang rutin mengadakan pertemuan untuk membahas berbagai permasalahan tingkat pusat dan daerah. Desain struktur dari governing council dan isu-isu yang dibahas hingga saat ini. Regional councils dibentuk sewaktu-waktu untuk menyelesaikan satu permasalahan atau isu yang berdampak kepada lebih dari satu daerah.

Struktur NITI Aayog akan dibentuk juga beberapa tim khusus:

- Research Wing: akan mengembangkan in-house keahlian sektoral berisikan ahli, peneliti, spesialis, dan akademisi.

- Consultancy Wing: akan menyediakan dana dan keahlian bagi kebutuhan lembaga pemerintah pusat atau daerah.

- Team India Wing: beranggotakan perwakilan dari setiap daerah dan lembaga, dan akan menjadi tempat untuk melakukan kolaborasi di tingkat nasional. Tiap perwakilan akan memastikan setiap daerah dan lembaga memiliki suara di NITI Aayog dan membangun komunikasi langsung antar lembaga dan pemerintah daerah.

Aspek lain yang penting terkait struktur organisasi adalah sumber daya manusia (SDM) dalam NITI Aayog. Sebagaimana diungkapkan di atas, NITI Aayog diharapkan akan lebih ramping dari Planning Commission. Untuk SDM, hanya setengah dari SDM Planning Commision yang ditarik ke dalam NITI Aayog. Di luar itu NITI Aayog berusaha menarik SDM berbakat dari luar dengan menawarkan gaji 30 persen lebih tinggi dari posisi yang sama di Planning Commission.

\section{Produk NITI Aayog}

Walau masih berusia singkat, tetapi sudah banyak produk yang dihasilkan oleh NITI Aayog. Salah satu yang paling sederhana adalah NITI Blogs dimana para anggota NITI menuliskan pemikiran mereka terkait perkembangan sosioekonomi terkini di masyarakat.

Gambar 2. Produk-produk NITI Aayog

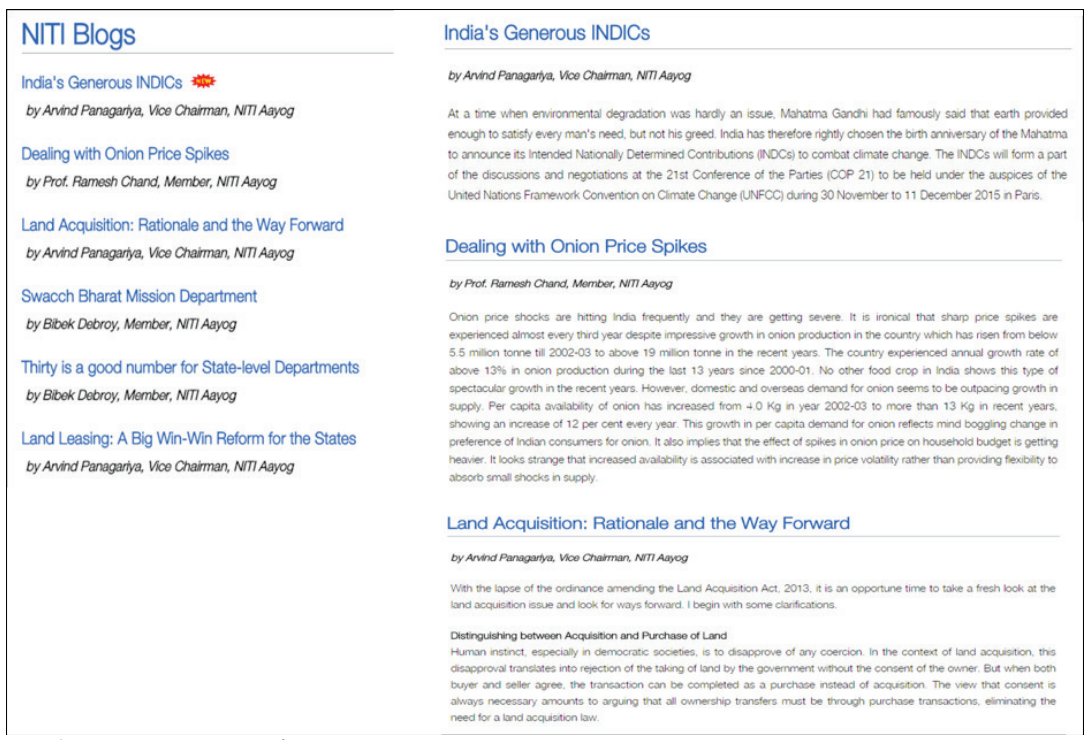

Sumber: Laman resmi NITI Aayog 
Berbagai policy/white paper juga telah dikeluarkan di antaranya:

1. Infrastructure: Powering Growth through Connectivity

2. Laporan tentang inovasi dan entrepreneurship

3. Laporan tentang pengembangan skill di India

4. Laporan tentang sanitasi (Swach Bharat Abhiyaan)

5. Laporan tentang sektor strategis industri

6. Skenario ketahanan energi hingga 2047

NITI Aayog juga melakukan beberapa inisatif baru di antaranya:

1. Atal Innovation Mission: Platform untuk inovasi dan promosi yang melibatkan akademisi, enterprenuer, dan peneliti untuk mendorong budaya inovasi dan litbang di India. Platform ini juga digunakan untuk sebagai hub inovasi skala dunia bagi India.

2. Self Employment and Talent Utilization: Techno-financial, inkubasi, dan program fasilitasi untuk mendorong berbagai aspek bisnis start-up, terutama yang berbasis teknologi.

3. Consultation Paper untuk Undang-Undang Reformasi regulasi

\subsection{National Economic and Social Development Board (NESDB) of Thailand}

The Office of the National Economic and Social Development Board (NESDB) adalah sebuah unit di bawah kewenangan Kantor Perdana Menteri Thailand yang menjalankan fungsi think tank di dalam kabinet. NESDB dibentuk di tahun 1950 oleh Perdana Menteri Plaek Pibulsongkram dengan tujuan utama sebagai sebuah institusi yang memberikan masukan kebijakan di bidang ekonomi kepada kabinet pemerintahan. Dalam perkembangannya, tugas dan fungsi NESDB bertambah menjadi tidak hanya memberikan masukan kebijakan di bidang ekonomi semata, tetapi juga kebijakan di dalam bidang kebijakan publik lainnya.

NESDB memiliki struktur yang berjenjang dalam menjalankan fungsinyaterutama dalam memberikan mesukan kebijakan kepada kabinet. Secara garis besar, NESDB terdiri dari dua sub-unit; yaitu Dewan Pengurus (Board) NESDB dan Tim Harian NESDB. Struktur NESDB yang terdiri dari dua bagian tersebut dibuat guna memastikan bahwa hasil kajian dan analisa kebijakan yang akan direkomendasikan oleh NESDB kepada kabinet telah melewati penelaahan yang ketat dan sistematis.

\section{Dewan Pengurus (Board) NESDB}

Dewan pengurus merupakan struktur tertinggi dari NESDB yang beranggotakan 15 orang ahli dan profesional di dalam kebijakan publik. Kelima belas anggota Dewan Pengurus tersebut terdiri dari sepuluh orang pakar kebijakan sosial ekonomi dan lima anggota lainnya adalah pejabat ex-officio pemerintahan yang terdiri dari Sekretaris Jenderal Komisi Pelayanan Publik, Direktur Anggaran, Direktur Jenderal Kebijakan Fiskal, Gubernur Bank Sentral Thailand dan Sekretaris Jenderal Tim Harian NESDB.

Dewan Pengurus memiliki tiga tugas dan kewajiban pokok, yaitu memberikan masukan dan pertimbangan kepada kabinet mengenai kebijakan pembangunan, memberikan masukan mengenai perkembangan terkini kebijakan kepada perdana menteri dan melakukan koordinasi terhadap pelaksanaan kebijakan sosial ekonomi yang melibatkan instansi pemerintah di tingkat kementerian, BUMN dan daerah

\section{Tim Harian NESDB}

Tim harian merupakan pelaksana teknis kegiatan think-tank NESDB. Tim Harian dipimpin oleh Sekretaris Jenderal yang otomatis menjadi anggota Dewan Pakar NESDB. Di dalam struktur organisasi tim harian NESDB, Sekretaris Jenderal dibantu 
oleh lima orang Sekretaris Deputi yang membawahi lima bidang pembangunan lintas sektor.

Sebagai sebuah lembaga think tank pemerintah, NESDB merupakan sebuah institusi yang dibentuk secara khusus untuk menyusun dokumen teknokratik perencanaan pembangunan yang berdasar pada hasil kajian ilmiah yang mendalam. Dalam menjalankan fungsi tersebut, NSDBE merupakan institusi yang memimpin penyusunan rencana pembangunan lima tahunan yang bersifat teknokratik, National Economic and Social Development Plan; dan rencana pembangunan empat tahunan tahunan, Government Administration Plan, yang lebih bertujuan untuk menterjemahkan manifesto politik yang dihasilkan oleh kabinet perdana menteri terpilih. NESDB memiliki fungsi strategis sebagai media yang memastikan bahwa perencanaan pembangunan yang dilakukan setiap tahunnya berpedomen kepada dua dokumen terrsebut yang memperhatikan konsep akademis dan juga landasan politik dari kabinet terpilih.

Dokumen perencanaan jangka menengah yang berlaku di Thailand saat ini adalah dokumen perencanaan ke-sebelas yang memiliki periode 2012-2016, selanjutnya disebut dengan "The 11th Plan". Secara garis besar, The 11th Plan memuat gap analysis antara kondisi sosial ekonomi Thailand saat ini dan visi Thailand sebagai sebuah negara dalam waktu lima tahun ke depan. The 17th Plan juga memuat agenda kebijakan yang menterjemahkan visi tersebut menjadi enam bidang sosial ekonomi. Sumberdaya manusia yang beranggotakan para peneliti beragam sektor di NESDB memungkinkan untuk menyusun dokumen perencanaan dengan basis akademik yang kuat. Laporan penelitian yang dihasilkan oleh para peneliti di NESDB merupakan sebuah publikasi akademis bertema mengenai kebijakan pembangunan yang dilakukan oleh Thailand. Dokumen perencanaan lima-tahunan yang diterbitkan oleh NESDB merupakan dokumen hidup yang menjadi acuan dalam dokumen perencanaan dan penganggaran tahunan yang dibuat bersama oleh NESDB, Biro Penganggaran, Kementerian Keuangan dan Bank Sentral Thailand.

Di dalam siklus perencanaan dan pengalokasian anggaran tahunan, NESDB memulai proses tersebut dengan menjadi institusi yang memimpin penyusunan kerangka kebijakan makroekonomi dan fiskal berkoordinasi dengan Kementerian Keuangan, Biro Penganggaran dan Bank Sentral Thailand. NESDB juga bertindak sebagai institusi yang memimpin proses penetapan agenda pembangunan tahunan berdasarkan kepada dokumen lime-tahunan "The 11th Plan" dan dokumen empat-tahunan "Governement Administration Plan".

Sistem perencanaan dan penganggaran di Thailand membagi dengan jelas kewenangan antar lembaga dalam menyusun program pembangunan yang berlandaskan pada kaidah akademis yang kuat dan terstruktur dengan baik. Terkait dengan substansi pekerjaan yang sangat bersifat akademis, sebagai sebuah lembaga think tank pemerintah, NESDB berperan penting dalam perencanaan pembangunan melalui penentuan kerangka kebijakan makroekonomi dan fiskal yang selanjutnya menjadi landasan dalam proses penghitungan besarnya pagu total anggaran pendapatan dan belanja pemerintah Thailand.

Selain hal tersebut, sebagai sebuah institusi yang memiliki sumberdaya manusia yang memahami konteks pembangunan Thailand secara mendalam dam multisektoral dan sebagai institusi yang merancang dokumen pembangunan jangka menengah, NESDB juga menentukan arah dan agenda pembangunan Thailand tahunan sebagai tahapan dalam pencapaian agenda pembangunan yang telah ditetapkan sebelumnya.

Di dalam keseluruhan proses perencanaan dan penganggaran sendiri, proses konsep dan substansi pembangunan dilakukan secara utuh oleh NESDB dan semua instansi terkait melaksanakan apa yang sudah diformulasikan oleh NESDB- 
termasuk di dalamnya adalah Biro Penganggaran (BOB) yang memimpin proses alokasi anggaran semua instansi pemerintah yang berpedoman oleh dokumen perencanaan yang NESDB hasilkan.

\subsection{Productivity Commission Australia}

Australia mempunyai super think tank yang diberi nama Productivity Commission (PC). Sebagaimana namanya, misinya adalah untuk meningkatkan produktivitas Australia secara keseluruhan. Perannya cukup sederhana sebagaimana dituliskan di bagian depan profil organisasi, yaitu membantu pemerintah untuk membuat kebijakan-kebijakan yang lebih baik dalam jangka panjang sesuai keinginan masyarakat Australia.

Sebelum menjadi PC, nama yang disandang adalah Dewan Penasehat Perencanaan Ekonomi Nasional (National Economics Planning Advisory) sesuai dengan UU (act) 1983. Kemudian berganti menjadi PC sejak 1998 melalui UU (Act 1998) dengan melebur Industry Comission. Struktur lembaga ini ada di bawah perdana menteri, dimana produk yang ada di KP langsung disampaikan ke perdana menteri.

Anggota komisi ditunjuk untuk jangka waktu 5 tahun yang ditetapkan perdana menteri setelah ada pertimbangan dalam sidang kabinet. Tuntutan profesional menyebabkan posisi ini tidak cocok untuk pejabat politik, sehingga sebagian besar komisioner diisi oleh professional dan akademisi. Kriteria pemilihan komisionel dilakukan dengan ketat dan persyaratan yang harus dipenuhi calon anggota komisi cukup banyak.

Kementerian Keuangan Australia membentuk panel seleksi yang akan merekomendasikan calon komisioner kepada sidang kabinet. Perdana Menteri memutuskan nama-nama yang jadi komisioner pada sidang kabinet tersebut. Dalam perjalanan KP sebagai lembaga think tank pemerintah Australia, hampir semua kebijakan pemerintah Australia berasal KP dan hampir seluruh penelitian kebijakan yang dilakukan KP rekomendasinya diterima pemerintah Australia.

Ada 4 keluaran utama dari PC adalah sebagai berikut: (1) studi penelitian tentang masalah-masalah yang jadi kepentingan publik, baik yang diminta oleh masyarakat luas atau pemerintah; (2) melakukan pemantauan kinerja dan patokan tentang layanan kementerian dan lembaga pemerintah; (3) menerbitkan laporan tahunan tentang produktivitas, perkembangan industri dan dan manfaat regulasi; (4) melakukan pemantauan atas iklim kompetisi.

Gambar 3. Produk Publikasi Productivity Commission

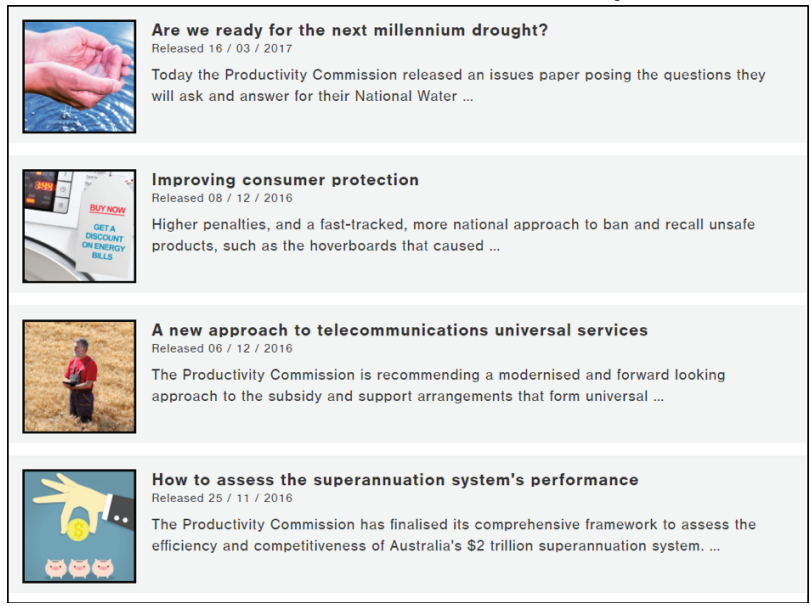

Sumber: Laman resmi Productivity Commission 


\section{Perkembangan Lembaga Think Tank Pemerintah di Indonesia}

Bagaimana sebenarnya perkembangan lembaga think tank di Indonesia? Meskipun tidak secepat laju di negara-negara maju, McCawley (2014) menyampaikan pada sebuah lokakarya bahwa pada akhir-akhir ini, kelompok lembaga pemikir di Indonesia jauh lebih aktif daripada sebelumnya, dan makin banyak memberikan sumbangan pemikiran pada perdebatan kebijakan publik.

Sementara dalam sebuah lokakarya yang difasilitasi Inspirit Innovation Circles dan AusAID (Oktober 2012) terungkap pentingnya lembaga think tank dalam konteks kebijakan publik yang perlu didukung oleh kemampuan: (1) menyampaikan hasil penelitian dalam situasi kritis yang membutuhkan pengambilan keputusan secara cepat; (2) menemukan solusi-solusi dari pemasalahan terkini; dan (3) membangun kredibilitas dan komunikasi efektif. Kesimpulan lainnya adalah bahwa selama ini kekuatan think tank Indonesia terletak pada sumber daya manusia yang semangat dan jaringan think tank dengan pemerintah, masyarakat, LSM dan perguruan tinggi. Pertanyaan selanjutnya adalah bagaimana peta lembaga yang bisa dikategorikan sebagai think tank Indonesia?

Inventarisasi lembaga yang berkapasitas sebagai think tank di Indonesia sebenarnya pernah dilakukan pada tahun 2012, yang dilakukan secara spontan sehingga hasilnya belum memuaskan. Teridentifikasi bahwa think tank masih terbatas persyaratan membangun lembaga pelaksana studi dan pemikir, dengan isu yang bersifat wacana dan belum dapat ditransformasikan ke kebijakan. Di Indonesia, beberapa universitas juga sudah memiliki pusat-pusat studi tapi belum pernah dilakukan inventarisasi apakah termasuk kategori menjalankan fungsi dan peran sebagai lembaga think tank atau tidak. Pada kenyataannya, memang lembaga think tank yang berbasis universitas dan korporat sebenarnya sudah cukup banyak di Indonesia. Meskipun demikian inovasi yang muncul belum dapat diterjemahkan ke dalam kebijakan.

Sebagaimana lembaga-lembaga think tank pemerintah yang telah diuraikan dalam kajian ini, maka adanya kebutuhan kelembagaan think tank dapat mengacu pada referensi tersebut.

Bappenas, dalam sejarahnya mempunyai fungsi think tank yang melekat, namun kelembagaannya tidak berkembang, termasuk tidak adany unit kerja pada level eselon satu atau dua dengan fungsi khusus sebagai think tank pemerintah. Padahal, tantangan pembangunan yang semakin kompleks membuat kebutuhan akan adanya lembaga itu pasti menguat. Berkaca ke Korea, Malaysia, India, dan Thailand yang lembaga think tank-nya dari waktu ke waktu mengalami penguatan dan revitalisasi.

Sebagaimana KDI dan PC, prinsip utama pembentukan lembaga think tank yang kredibel adalah perlunya independensi. Untuk menjadikan lembaga think tank yang mandiri tersebut perlunya posisi lembaga think tank yang mempunyai otoritas di dalam sistem organisasi Bappenas. Independensi dapat dibangun melalui mekanisme kerja, profesionalisme, serta kualitas kapasitas kerja yang kuat.

Dari hasil serial FGD yang dilakukan, kajian ini mengerucut pada beberapa opsi posisi think tank didalam struktur lembaga di Kementerian PPN/Bappenas, yaitu sebagai: (1) pemerintah dapat melakukan revitalisasi sebagian organ di Bappenas untuk menjadi think tank; (2) melepaskan organ think tank di Bappenas dan dijadikan lembaga khusus think tank di bawah Bappenas, seperti Badan Pusat Statistik (BPS) dan Lembaga Kebijakan Pengadaan Barang dan Jasa Publik (LKPP); dan (3) membentuk kelembagaan baru think tank di bawah presiden dengan memanfaatkan sumber daya kelembagaan think tank yang sudah ada di pemerintahan seperti Bappenas dan Litbang Kementerian dan Lembaga.

Pertama, pemerintah dapat melakukan revitalisasi sebagian organ di Bappenas untuk menjadi think tank. Sisi positifnya adalah terjadinya mekanisasi 
yang otomatis 'bridging research to policy' dan 'bridging knowledge to power' dalam sebuah mekanisme internal di Bappenas. Dalam penyusunan dokumendokumen perencanaan yang teknokratik maka struktur ini sangat memudahkan dalam operasionalisasinya. Sisi negatif yang perlu dikedepankan adalah adanya kekhawatiran bahwa policy research kembali ditinggalkan sebagaimana Bappenas selama ini melakukan penyusunan dokumen teknokratik yang lebih banyak mengandalkan expert judgment daripada rekomendasi dari policy research. Di samping itu Bappenas pada awalnya juga diamanatkan untuk membentuk kelembagaan think tank pemerintah, namun dalam perjalanannya tidak pernah dilakukan. Fungsi perencanaan dan penganggaran sudah sangat menguras waktu dan tenaga, sehingga pembentukan kelembagaan think tank yang masih embrio diperkirakan tidak dapat optimal.

Kedua, melepaskan organ think tank di Bappenas dan dijadikan lembaga khusus think tank di bawah Bappenas. Kelebihan dari opsi ini adalah kedekatan akses lembaga kepada pengambil keputusan tertinggi makin memudahkan mekanisme penyampaian rekomendasi kebijakan. Di samping itu sebagai anggota kabinet, lembaga think tank juga dapat berperan dalam setiap pengambilan keputusan. Kekurangannya adalah sebagai lembaga embrio, penempatan struktur yang tinggi dikhawatirkan dapat menjadi kontraproduktif. Besar kemungkinan terjadi ketidak sinkronan antara kualitas keluaran lembaga think tank dengan kebutuhan pengambilan keputusan.

Ketiga, membentuk kelembagaan baru think tank di bawah presiden dengan memanfaatkan sumber daya kelembagaan think tank yang sudah ada di pemerintahan seperti Bappenas dan Litbang Kementerian dan Lembaga yang sebelumnya juga mempunyai tugas sebagai jembatan atas ilmu pengetahuan kepada kebijakan (bridging knowledge to policy).

Dalam bentuk opsi lembaga think tank, tugas utama lembaga tersebut adalah: (1) Melakukan kajian kebijakan pembangunan nasional (termasuk quick response policy, studi evaluasi kebijakan pelaksanaan pembangunan); (2) Menformulasikan isu-isu strategis dan menyusun kerangka makro ekonomi; (3) Menyusun laporan perkembangan pelaksanaan RPJP, RPJMN, dan RKP secara berkala; (4) Menerbitkan jurnal dan buku riset analisa kebijakan; (5) Melakukan pembinaan fungsional peneliti kebijakan dan perencana.

Kajian ini juga mengajukan beberapa saran langkah tindak-lanjut sebagai berikut: (1) Peningkatan kemampuan peneliti kebijakan dan perencana melalui pelatihan-pelatihan singkat dan magang di lembaga-lembaga pemikir di dalam negeri dan di luar negeri; (2) Peningkatan kerjasama riset dengan lembaga riset pemerintah dan non pemerintah di dalam negeri dan di luar negeri; (3) Penyusunan mekanisme kerja lembaga think tank, terutama yang berkaitan dengan instansi pemerintah sebagai pengguna; dan (4) Mengadakan berbagai upaya peningkatan kapasitas organisasi dan kualitas output.

\section{Kesimpulan dan Rekomendasi}

\subsection{Kesimpulan}

a. Perkembangan zaman menuntut sebuah pemerintahan yang harus dapat mengikuti kemajuan peradaban. Pemerintahan masa kini harus dapat memberikan manfaat lebih besar buat masyarakatnya melalui terobosanterobosan yang dihasilkan oleh ilmu pengetahuan. Salah satunya adalah tentang lembaga think tank pemerintah yang berperan besar dalam mengakselerasi pembangunan sebuah negara.

b. Lembaga think tank pemerintahan pada dasarnya berfungsi sebagai jembatan antara ilmu pengetahuan dan kebijakan pemerintah. 
Kompleksitas permasalahan pembangunan menjadi tantangan pemerintah untuk dikelola dan diatasi berdasarkan ilmu pengetahuan yang bersumber dari penelitian akademis. Lembaga think tank merumuskan bagaimana ilmu pengetahuan tersebut ditransformasikan menjadi riset kebijakan sehingga dihasilkan solusi kebijakan yang teruji.

c. Kita dapat menengok Korea Selatan (Korsel) yang sekarang menjadi salah satu raksasa ekonomi dunia. Apa yang membuat negara bekas jajahan Jepang ini melejit sebagai salah satu kekuataan baru dalam perekonomian dunia dengan maksimal? Salah satu faktor dominan itu adalah berkat adanya skenario pembangunan jangka panjang, menengah dan pendek yang diperankan dengan sangat baik oleh lembaga think tank yang dimiliki pemerintahnya. Lembaga itu adalah Korean Development Institute (KDI). KDI yang merumuskan sebuah rencana strategis yang memuat di antaranya investasi penelitian dan pengembangan teknologi tinggi, penyediaan infrastruktur, membangun basis industri manufaktur yang kuat, serta menyiapkan sumber daya manusia yang berkualitas. KDI menjadi jembatan yang mulus yang mengantarkan stok ilmu pengetahuan yang ada di Korsel untuk disinergikan dan diimplementasikan melalui kebijakan pemerintahan Korsel.

\subsection{Rekomendasi}

a. Dalam struktur pemerintah pusat ada fungsi think tank pada Badan Perencanaan Pembangunan Nasional (Bappenas). Bappenas sebagai think tank cakupan tugasnya adalah meliputi fungsi pengkajian kebijakan di bidang perencanaan pembangunan, fasilitasi instansi pusat dan daerah, serta kerjasama dengan perguruan tinggi. Alat kelengkapan dasar sebagai lembaga think tank seperti fungsi penelitian kebijakan tidak dilakukan Bappenas, hal dasar yang sangat sangat tertinggal. Menilik pada hal ini maka fungsi think tank di Bappenas perlu mendapat revitalisasi.

b. Merujuk pada perkembangan peran lembaga think tank pemerintah sebagaimana di Korsel dan Australia, serta negara-negara berkembang yang mengaplikasikan fungsi think tank di pemerintahan (seperti Thailand dan India), maka pemerintah Indonesia sudah saatnya memikirkan fungsi think tank di pemerintahan. Lembaga think tank ini yang akan memberikan panduan melalui rekomendasi kebijakan yang kredibel untuk memudahkan pengambilan keputusan.

c. Untuk mewujudkannya ada tiga opsi bagi Bappenas (juga pemerintah) dengan pertimbangannya:

- $\quad$ Pertama, pemerintah dapat melakukan revitalisasi sebagian organ di Bappenas untuk menjadi unit kerja think tank pemerintah. Opsi ini merujuk pada lembaga think tank di Thailand (NSEBD), dimana lembaga perencanaan dan penganggaran diperkuat oleh fungsi think tank.

Kedua, jika opsinya transformasi dari Bappenas menjadi lembaga think tank pemerintah secara keseluruhan, maka rujukannya adalah lembaga think tank pemerintah India (NITI Aayog).

- Ketiga, melepaskan organ think tank di Bappenas dan dijadikan lembaga khusus think tank di bawah Bappenas. Opsi ini merujuk pada lembaga think tank pemerintah Korea (KDI), dimana keberadaannya sebagai lembaga otonom yang mendukung lembaga perencanaan dan penganggaran.

- $\quad$ Keempat, membentuk kelembagaan baru think tank di bawah presiden dengan memanfaatkan sumber daya kelembagaan think tank yang sudah ada di pemerintahan seperti Bappenas dan Litbang 
Kementerian dan Lembaga yang sebelumnya juga mempunyai tugas sebagai jembatan atas ilmu pengetahuan kepada kebijakan (bridging knowledge to policy). Opsi ini merujuk pada lembaga think tank pemerintah Australia (PC).

d. Fungsi lembaga think tank pemerintah, baik di Bappenas atau lembaga tersendiri membutuhkan perubahan budaya birokrasi dan konsep berpikir yang berbeda dibandingkan sebagai birokrat secara umum, untuk itu perlu dikembangkan beberapa hal sebagai berikut: Pengkajian kebijakan pemerintah lebih berkembang sebagai pengkaji kebijakan yang aplikatif, untuk memberikan rekomendasi solusi aplikatif terhadap permasalahan di masyarakat/ kepemerintahan yang berkembang. Untuk itu, sebagai peneliti SDM think tank harus terlibat langsung dalam proses kepemerintahan/ perencanaan pembangunan. Kredibilitas dibangun melalui penguasaan validitas proses, kualitas metodologi kajian, profesionalitas dan integritas;

i. Secara umum budaya organisasi pemerintah yang memungkinkan berkembangnya perkuatan fungsi think tank membutuhkan perubahan konsep berpikir dan bentuk komunikasi yang berubah, antara lain: menjadi organisasi yang lebih egaliter, penghargaan atas karya individu, insentif dan penghargaan kedudukan yang sama antara pimpinan struktural dan fungsional, hubungan pimpinan yang luwes bukan atasan-bawahan, bentuk komunikasi yang memungkinkan peneliti bebas untuk berpikir dan menyampaikan pemikirannya sehingga memungkinkan kreativitas dan inovasi berpikir yang mumpuni.

ii. Penempatan SDM di dalam unit kerja think tank perlu mempertimbangkan hal-hal antara lain: minat dan kemampuan untuk melakukan kajian kebijakan publik, kemampuan bekerja secara individu namun juga dapat berinteraksi secara tim, minat pengembangan diri, integritas sebagai seorang peneliti;

iii. Pimpinan di dalam unit kerja struktural think tank harus pula memenuhi perubahan karakter antara lain: pemimpin yang egaliter dan terbuka dalam berkomunikasi, menghargai kreatifitas/karya staf, mempunyai kapasitas pengetahuan sebagai peneliti, memotivasi berkembangkanya pemikiran kreatif dan inovatif.

e. Alat kelengkapan yang lebih spesifik dari lembaga think tank pemerintah ini adalah: (1) melakukan riset dan penelitian kebijakan; (2) melakukan laporan berkala tentang perkembangan pelaksanaan program pemerintah dalam rencana strategis jangka panjang, menengah, dan pendek; dan (3) melakukan evaluasi implementasi kebijakan baik program maupun regulasi; (4) melakukan sinergi agar akumulasi ilmu pengetahuan dapat dijembatani dalam kebijakan pemerintah Indonesia. 


\section{Daftar Pustaka}

Australian AusAID. 2012. Australia-Indonesia Partnership for Pro-poor Policy: The Knowledge Sector Initiative. Canberra (Australia).

Blondal, Jon R, Sang In-Kim, et al. 2006. Budgeting in Thailand, OECD Journal on Budgeting. OECD

Joong-Kyung Choi. 2013. Upside-Down Success Story of Korea's Economic Development. Daewon Publishing. Seoul (Korea).

Korea Institute for Industrial Economics \& Trade. 2013. A Specialized Think tank for Korean Industrial Economic Policy. Seoul (Korea).

McCarthy, Ibrahim, et al. 2010. Review of Social Science Capacity Building Support to Indonesia's Knowledge Sector. Knowledge Sector Initiative Report. AusAID. Jakarta (Indonesia).

Muhyiddin, Muhammad NA, Hidayat MF, Anindito IA, Suhardiono Y, et al. 2014, Studi Model Hubungan Kerja Kelembagaan Think Tank Pemerintah dengan Penentu Kebijakan. Tim Analisa Kebijakan. Bappenas. Jakarta (Indonesia).

Riyadi DMM, Guspika, Santoso B, Suhermanto H, Lukito PK, Haryanto, Yulius, Muhyiddin, Muhammad NA, Mulyo SA, Darmawijaya, et al. 2014. Reposisi Bappenas. Tim Analisa Kebijakan. Bappenas. Jakarta (Indonesia).

Riyadi DMM, Guspika, Santoso B, Suhermanto H, Lukito PK, Haryanto, Yulius, Muhyiddin, Muhammad NA, Mulyo SA, Darmawijaya, Nugroho $\mathrm{H}$, et al. 2014. Think Tank Bappenas: Sebuah Pemikiran. Tim Analisa Kebijakan. Bappenas. Jakarta (Indonesia).

Suryahadi, Asep, 2014, Konsep, Bentuk, Peran, Prospek, dan Tantangan Lembaga Think tank di Indonesia. SMERU Institute. Jakarta (Indonesia). 